\title{
Is Graeco-Roman Medicine Holistic? Galen and Ancient Medical-Philosophical Debates
}

\author{
P. N. Singer
}

\begin{abstract}
The chapter attempts to analyse what can sensibly be understood by the term 'holism', which is very frequently used in relation to ancient medicine. It identifies three fundamental senses of the term - (1) unity of mind and body, (2) a unitary conception of the body itself, (3) unity of the body with its larger environment or cosmos - and considers ways in which both ancient medical theory and ancient diagnostic and clinical practice do or do not correspond with those conceptions. The paper focuses on Galen, but also contextualizes his approach within the Graeco-Roman medical and philosophical tradition, and compares it with others available in the ancient world, including those of Celsus and the Methodists. It is argued that a complex and nuanced picture emerges, within which, however, attention to overall states of the body tends to predominate over localization, and there are intricate accounts of the mutual dependence of 'soul' and 'body.'
\end{abstract}

\section{Introduction}

Graeco-Roman medical thought, in common with other 'alternative' or non-western medical traditions, is very often stated to offer a holistic approach to health, and is (almost equally often) celebrated for that. But the terms 'holism' and 'holistic' tend to be used vaguely, or at least without any accompanying definition. (Further on these problems, and in particular on those arising from modern projections of 'holism' onto Hippocrates, see Helen King's chapter in this volume.) In this paper I want to be more precise about the way, or rather the ways, in which the term may be applied to ancient medical thought, and to consider the practical significance of the holisms, or arguments in relation to holism, thus identified - both how they affected clinical practice and how they were used to express rivalries or disputes over competence. My focus 
here will not be on the second point, that of the value judgement in relation to the various holisms we may encounter, although some remarks relevant to that may be offered in passing. My aims rather are:

(1) to pin down what we mean by holism, and in particular its different possible senses as relevant to the Graeco-Roman material;

(2) to consider which (if any) of these Galen's therapeutic approach conforms to, and in what ways this is important for his approach to health;

(3) to consider also the limitations to holism in Galen, that is, important senses in which his approach seems to go in a very different direction from some of the senses of holism identified;

(4) to put this Galenic approach in relation to other ancient medical approaches.

To begin with, then, I suggest three main senses of 'holism' of particular relevance to Graeco-Roman medicine:

(a) mind-body holism: mind (or soul) and body are, in an important clinical sense, a unity;

(b) whole-body holism: the whole body must be considered in any pathological state; this sense includes, or may be divided into, two further senses:

(b1) the whole body must be considered in medical diagnosis;

(b2) the body as a whole, rather than individual parts, are the focus of medical treatment;

(c) one-with-the-cosmos holism: we as human beings are part of a larger whole, conceived in terms of our environment or of the cosmos in an even larger sense, in a way which is importantly relevant to health.

The paper will proceed, then, by considering Graeco-Roman thought on health, disease, diagnosis and clinical treatment in relation to each of the above senses of holism. In each case we shall examine Galen first, and in most detail, but will also consider the relationship of the Galenic model to other models and debates within ancient medicine and philosophy, considering both the classical (Hippocratic and Platonic) background and practitioners closer to Galen's own time, in the first and second centuries CE.

2

\section{Mind-Body Holism}

\subsection{Galenic Complexity}

The Galenic picture here is a somewhat complex one. There are two important senses in which Galen presents the pathology and treatment of the soul, or 
mind, ${ }^{1}$ as a separate domain from that of (the rest of) the body, and thus moves in a fundamentally different direction from (a)-type holism. ${ }^{2}$ First, there is a clear Galenic category of medically-defined illnesses which are (in our terms) mental or neurological: the 'medical psychic impairments' ${ }^{3}$ - such items as mania, lèthargos, paraphrosynē, epilēpsia, or melancholia. These are understood essentially as impairments of brain function. The diagnostic distinctions between them consist in the differences in cognitive, behavioural or neurological disorders which they present; to this extent their pathology is conceptually distinct from that of the rest of the body. Their aetiology, meanwhile, depends $\left(\right.$ largely $\left.{ }^{4}\right)$ on the same system, that of the hot, cold, wet and dry and their imbalances, which underpins Galen's system in general.

For example, paraphrosyne or 'derangement' is understood as an impairment of the soul's 'leading-faculty' (hêgemonikon), located in the brain. This admits of further diagnostic distinctions, depending on precisely which function of the brain is impaired. Here as with other 'mental' disturbances, the aetiology depends closely on the opposition of excessive heat, leading to over-excited states (e.g. mania) and excessive cold, leading to depressed ones (e.g. lèthargos, melancholia). ${ }^{5}$

In both these respects, then - the diagnostic use of differential mental impairment and the focus on physical aetiologies - Galen's account of medical psychic impairment begins to look not very dissimilar from a standard contemporary one. It is only 'holistic' in the minimal sense that bodily factors have an effect on the soul or mind.

1 These two terms cannot, of course, be taken as co-extensive. (For the problem of locating an ancient category of 'mental', or of mapping the ancient discourse on to modern terminology, see now e.g. Thumiger and Singer (2018) 18-24.) But, at the risk of simplification, we may say that there is, at least in pathological contexts, a rough equivalence between the domains covered by Galen's $p s y c h \bar{e}$ (and cognates) and those covered by our terms 'mental' and 'psychological' - though the provisos must be made, both of the overlap with our category of 'neurological' and of the distinct nature of the ethical discourse on the soul, on which see further below.

2 For a fuller account of Galen's variety of approaches to and therapy for soul pathology, see Singer (2018); and cf. Devinant (2018).

3 I adopt this terminology (cf. Singer 2018) to separate this distinctly medical category from the pathe psychès considered as emotions or affections, and also to do justice to the imprecise equivalence between the Greek term and our 'psychological' or 'mental.'

4 As we shall see further below, there is also acknowledgement of the possibility of psychogenic causes of some of these items.

5 See in particular Galen, Distinctions in Symptoms (Symp. Diff.) 3 (VII.55-62 к. $=216-26$ Gundert) and Affected Places (Loc. Aff.) 3.6-12 (VIII.16o-204 K.), in conjunction with Singer (2018) 386-93; also Devinant (2018); Julião (2018). 
The second - and again, clinically crucial - sense in which Galen seems to be markedly non-holistic is in his ethical, as opposed to medical, account of 'psychotherapy.' Here, he presents the diagnosis and treatment of the passions or affections of the soul (pathē psychess), ${ }^{6}$ as a separate discipline, different in kind from the rest of medicine. In Affections and Errors of the Soul and Avoiding Distress, he offers the reader, or potential patient, a range of quasi-medical interventions for the cure of the soul, which are quite distinct from the typical medical interventions 'for the body' (diet, exercise, drugs, blood-letting). Here the clinical techniques are rather: interaction with a personal supervisor to provide impartial criticism of one's irrational behaviour; self-examination; visualization of the relative attractiveness of virtuous and vicious behaviour; self-training to anticipate negative outcomes; certain kinds of daily reading or recitation. These kinds of intervention or discipline, sometimes called the therapy of the word, are evidenced also in other authors, for example Plutarch, Seneca, Marcus Aurelius, Epictetus. ${ }^{7}$

In the interests of concision, the following extract from Affections will suffice to exemplify this separate domain of the pathē psychēs - quasi-medical, but involving philosophical rather than expert medical intervention:

The affections of the soul ( $\pi \dot{\alpha} \theta \eta \psi \psi \chi \chi \eta \hat{\zeta})$ are ... rage, anger, fear, distress,

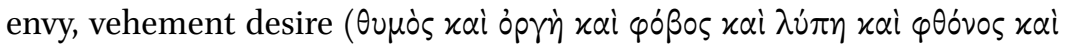
$\dot{\varepsilon} \pi(\theta u \mu i \alpha \sigma \varphi \circ \delta \rho \alpha)$... How should one excise these affections? ... If you find such a person [sc. who will speak the truth to you] ... ask him to make evident to you directly which ... affections he sees in you, emphasizing the gratitude you will feel towards him: he will be your saviour, even more so

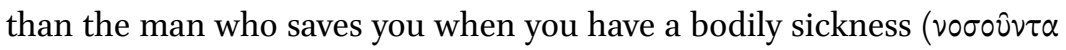
$\tau \dot{0} \sigma \hat{\omega} \mu \alpha)$.

GALEN, Affections and Errors of the Soul (Aff. Pecc. Dig.) $1.3(\mathrm{~V} .9 \mathrm{~K} .=7-8 \text { de Boer })^{8}$

6 The choice of English translation for pathos is problematic. While 'affection' (the option chosen here) is less than idiomatic, 'passion' is misleadingly dramatic and 'emotion', conversely, too neutral: for Galen a pathos psychēs is always a negative event, though they vary in severity. For Galen on the pathè see Manuli (1988); Hankinson (1993); Gill (2010); Kaufman (2014); Singer (2013); Singer (2019); Singer (forthcoming b).

7 The Galenic works appear in English translation with substantial notes and introductions discussing the therapeutic techniques in question, and their philosophical background, in Singer (2013). For discussion of them see especially Gill (2010), further Singer (2018), esp. 394-99; Singer (2019).

8 Translations are my own unless otherwise stated. However, published translations of the texts quoted are in any case mentioned in the bibliography at the end of the chapter, for the reader's ease of reference. 
But there are other Galenic texts which might be considered to offer something more like (a)-type holism, texts which either suggest that the soul actually is identical with the body, or bodily in its fundamental nature, or present a more reciprocal, or closely 'intertwined', causal relationship between body and soul than that suggested at the end of the first paragraph of this section, above.

Famously, Galen posits a form of soul-body identity thesis (albeit in a work whose overall thesis, and title, correspond rather to a more straightforward soul-body dependence thesis):

... it is preferable to say, not that it is slave to the body, but that this is actually what the mortal part of the soul is: the mixture of the body ( $\tau \dot{\eta} \nu$

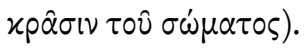

GALEN, The Soul's Dependence on the Body $(Q A M) 4(\mathrm{IV} .782 \mathrm{~K} .=26$ Bazou $)$

This is followed a few lines later (IV. $783 \mathrm{~K} .=27$ Bazou) by the argument, albeit in a dialectical context, that the substance or essence (ousia) of the soul should be equated with a bodily mixture (krasis). There has been much discussion of this apparent statement of an identity thesis, and of its relationship with Galen's overall views. ${ }^{9}$ It will suffice here to observe that Galen is at the very least strongly drawn towards a fundamentally physical understanding of the soul, in a way evidenced not just by philosophical pronouncements such as that above, but also by remarks offered in the context of clinical discussions and also of physiological discussions, where he highlights the fundamental role of a form of breath or pneuma in accounts of the soul's activities. ${ }^{10}$

Of particular interest for our present discussion are the practical claims made, for example that diet and physical activity, via the mixture they produce in the body, actually provide a basis for ethical improvement:

The capacities of the soul depend on the mixtures of the body ( $\tau \alpha i \varsigma$

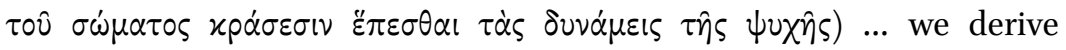
good-mixture from our food and drink and other daily activities, and on

$9 \quad$ Amid much recent literature, see especially: Lloyd (1988); Hankinson (1991a), (1991b), (2006); Vegetti (1999); Von Staden (2000), (2011); Tieleman (2003); Donini (2008); Gill (2010); Singer (2013) 18-33 and 335-69; Havrda (2017).

10 E.g. at Causes of Symptoms (Caus. Symp.) 2.5 (VII.191 K.), where he asserts that the soul either uses pneuma, blood and heat as its primary instruments or actually is those physical things. So, Galen toys with a thesis of soul-pneuma identity too, but seems ultimately to reject it, and indeed consistently refrains from committing himself on 'the substance of the soul': see Frede (2003); Donini (2008); Singer (2013) $340 \mathrm{nn} .19$ and 21; Singer (forthcoming a); and further on pneuma in Galen see Julius Rocca's chapter in this volume. 
the basis of this mixture are then able to improve the virtue of the soul (

GALEN, $Q A M 1$ (IV.767-68 K. = 7 Bazou $)$

A further analysis comes near the end of the same work:

This part [sc. negative outside influences] accounts for bad habits ... and

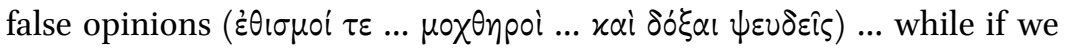
are educated by good, upright individuals we acquire correct opinions and good habits. But it is on mixtures that depend cleverness and fool-

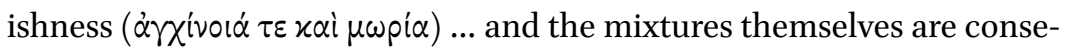
quent on genetic factors and a daily regime involving good humoral fluid

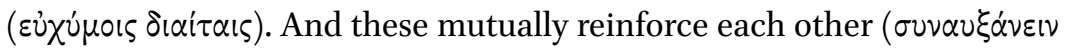
$\alpha \lambda \lambda \eta \lambda \alpha)$... People become quick-tempered because of a hot mixture, but then through their quickness of temper inflame their innate heat

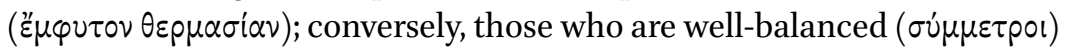
in their mixture have well-balanced motions ( assisted towards good humoral mixture ( $\varepsilon \dot{\chi} \chi u \mu i \alpha \nu)$.

GALEN, $Q A M 11$ (IV.820-21 K. = 87-88 Bazou)

We have here a complex interaction of factors - nature, training and outside influence, habit, established soul characteristics - contributing to the ethical and cognitive health of the human being; moreover, a close reciprocal relationship is envisaged between the physical factors from which soul characteristics are ultimately derived and those developed characteristics themselves. We may well interpret this reciprocal, or closely 'intertwined, causal relationship between body and soul, as broadly in line with (a)-type holism.

There seems, then, to be a tension in Galenic thought, between, on the one hand, two therapeutic approaches - that found in his account of medically-defined psychic impairments, and that found in his ethical 'psychotherapeutics' - which both in different ways see the psyche as something to be diagnosed and cured as an entity separate from the rest of the body, and another approach which tends to regard the health of body and health of soul as fundamentally inextricable.

We shall proceed now to consider some further texts which elaborate this 'inextricability' view, in the context of the maintenance of human health. Before doing so, we should address the problem of what may seem like a second tension, within those texts which advance such an inextricability view. For on the one hand we have the apparent identity statements, or theoretical statements of a fundamentally physical nature of the soul, considered above; and 
on the other we have a number of passages, still emphasizing the close interconnectedness of soul and body, but doing so while talking in an untheorized way of soul and body - and their health - as separate items.

This second tension is, I suggest, fairly readily resolvable, in practical if not in detailed theoretical terms. Here it may be helpful to introduce the concept of 'pragmatic dualism.' That is: you may believe, theoretically or ultimately, that mind and body are parts or aspects of a single entity. But you may still find it useful, in everyday and indeed in clinical contexts, to speak of mind and body and their interaction. This, I would suggest, is common linguistic practice also in contemporary medicine. The mind, and the mental - and the distinction between them and the body or the physical - are concepts regularly employed in everyday communication, including in interactions between doctors and patients. And they continue to be employed even by individuals whose theoretical view may be that mind is reducible to body, that they are ultimately one. So, using dualist language in this sense may not be in conflict with (a)-type holism. One may be using 'pragmatic dualism' in ordinary language to specify particular subsets of event or experience ('of the soul', 'of the body'), even while regarding the two as aspects or inextricably linked parts of what is, in the most important clinical sense, a unity.

Particularly interesting in this context is Galen's large work on everyday healthy living, Matters of Health. Here, there is an undeniably physical basis to most of what Galen is saying about the soul. However, in the context of an account of two sets of experiences and interventions which can be seen, in a practical everyday sense, as different in kind, we will end up talking quite a lot about the soul and the body as different things, and indeed about their interaction. But a strong statement of such interaction, even if it uses the pragmatically dualistic language, may still count as some kind of mind - body, or (a)-type, holism.

For example, Galen has a strong and detailed view about the way in which a range of mental or emotional experiences - rage, worry, distress, weeping, resultant insomnia - may negatively affect physical health.

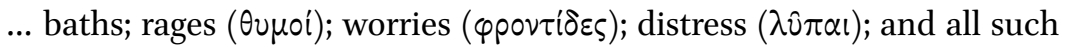
things which pretty nearly transform the mixture through their every shift ...

GALEN, Matters of Health (San. Tu.) 1.5 (VI.28 K. = 14 Koch)

For, indeed, rage, weeping, anger, distress, worry which is more than it should be, as well as significant sleeplessness ( $\alpha \gamma p u \pi v i \alpha)$ arising from them, provoke fevers, and become the starting-points of major diseases, 


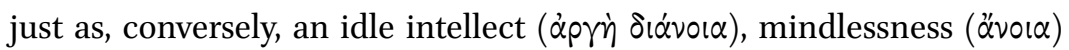
and a soul which is completely lacking in spirit ( $\left.\ddot{\alpha} \theta \mu \circ)^{\prime}\right)$ often bring about

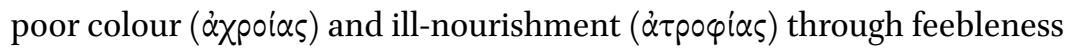
of the innate heat.

GALEN, San. Tu. 1.8 (VI.4O-41 K. = 19-20 Koch)

On the one hand, there is here a clearly-defined separate category, that of the pathe $p s y c h \bar{s}$, which are different in kind from diet, exercise and baths; on the other, they are listed indiscriminately alongside those latter kinds of factor. And, crucially, the mechanism by which they affect physical health is the same: these mental disturbances disrupt the balance by causing excessive heat, cold, or dryness, just as the wrong diet or baths will.

Indeed, Galen further elaborates this understanding of emotional disturbance, of the pathē psychēs, as functioning within a physical model of explanation:

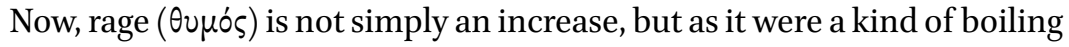
of the hot in the heart ... The internal heat increases in those suffering

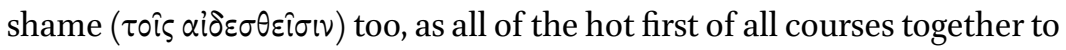
the inside ... For in shame the breath $(\pi v \varepsilon \hat{\mu} \mu \alpha)$... is stirred about all over the place both inside and about itself, along with all the blood, just as it is in people suffering anxiety ( $\tau \hat{\omega} \nu \dot{\alpha} \gamma \omega \nu i \omega \dot{\nu} \tau \tau \omega \nu)$.

GALEN, San. Tu. 2.9 (VI.138-39 K. = 61 Koch)

It is possible to observe its [sc. the internal heat's] motions manifestly in many other affections, but especially those of the soul ( $\dot{\varepsilon} \nu \alpha \dot{\alpha} \lambda$ or $\tau \varepsilon$

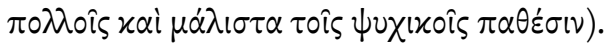

GALEN, Caus. Symp. 2.5 (VII.191 K.)

There is an inextricable relationship between the pathe of the soul - or at least an important set of them - and the physiological complex of innate heat, blood and pneuma, a relationship explored by Galen in considerable detail.11 This enables one to observe bodily changes which are specific to particular emotional states, and thus even to diagnose such states on that basis.

On the other hand, it can be crucial for diagnosis and treatment to know whether a particular state has its origin in the soul or in the body. An example is the lovesick woman in Prognosis. The case, and Galen's quasi-theatrical

11 For further discussion and a fuller range of the most relevant Galenic texts, see Singer (2017). 
success in his self-presentation of it, are well known. Here, I simply draw attention to one feature of the case in Galen's account of it, namely the either - or nature of his differential diagnosis. After his first consultation, Galen says,

I decided she was suffering from one of two things: from a depression caused by black bile ( $\mu \varepsilon \lambda \alpha \gamma \chi 0 \lambda i x \omega \hat{s} \delta \nu \sigma \theta \nu \mu \varepsilon \hat{\imath})$ or from some distress $(\lambda \nu \pi \circ v \mu \varepsilon \dot{\varepsilon} \nu \nu)$ she was unwilling to confess.

GALEN, Prognosis (Praen.) 6 Nutton (XIV.631 K. = 100-102; trans. NUTTON, slightly adapted)

The answer turns out to be the latter: the woman is eaten up by passion for a dancer of the name of Pylades - as Galen dramatically demonstrates by taking her pulse at the moment that this name is mentioned. But the point is that in a case where symptoms may look very similar, it is of clinical importance to establish which the underlying cause was: a physical one or a psychogenic one. Relevant material could be added here from the Commentary on Hippocrates' Epidemics VI, where Galen describes a number of cases of psychogenic illness, involving in particular forms of anxiety, grief, obsession or delusion, several of them with fatal outcomes. ${ }^{12}$ In one sense, such cases again emphasize the separateness of the psychic as a diagnostic category; but at the same time they serve to show again the inextricable nature of the soul-body organism.

One could, given more space, add further Galenic passages which elaborate on this intertwined or reciprocal interaction between soul and body. Galen asserts the value of a good daily regime for the character as well as the body; but at the same time claims to have cured people suffering from a variety of physical conditions by attending to 'unbalanced motions' arising in the soul. ${ }^{13}$ In the latter context, he also gives detailed prescriptions for various imperfect conditions of the soul, ranging from musical activities and poetry composition to sporting activities including fighting and hunting. He summarizes the point:

... the person who is capable of employing these arts [sc. those related to music and physical exercise] will best educate both body and soul. GALEN, San. Tu. 1.7 (VI.37 K. = 18 Koch)

The notion that emerges of a mind-body complex, with an intricate causal intertwining of health of 'soul' and health of 'body', seems to give us one strong sense of holism to which Galen does subscribe, and perhaps also - to return

12 See especially Hipp. Epid. VI ch. 8 (485-87 Pfaff).

13 San. Tu. 1.6 (VI.32-33 K. = 16 Koch); 1.8 (VI.39-42 K. = 19-20 Koch). 
briefly to the evaluative question - one where contemporary readers may find the approach fruitful or at least suggestive.

\subsection{Hippocratic and Platonic Background}

The legacy of Hippocratic and Platonic models seems especially important here. The former is relevant in the following way. The Hippocratic Corpus in general terms lacks a clearly defined notion of the mental or (with few exceptions) the soul, and therefore does not tend to regard mental disorders as different in category or fundamental character from any other disorders. ${ }^{14}$ More specifically, a range of Hippocratic texts dealing with diagnosis, disease causation, or the maintenance of health presents lists of physical and (in our terms) psychological factors and/or symptoms alongside each other, in a way very similar to that which we observed above in Galen's Matters of Health. Indeed, Galen's approach in this area - both the identification of relevant factors affecting health, and the prescriptions, both crucially centring on diet, exercise and physical environment - is clearly fundamentally moulded by that Hippocratic discourse..$^{15}$ (And we might wish to say that his approach in this area represents the most 'intertwined' or holistic part of his work.)

The parallelism that we have observed in some Galenic texts between health of body and health of soul, meanwhile, has a clear Platonic heritage. Such a parallel is a recurrent feature of many Platonic dialogues, as is the additional specification - also observed above in Galen - that the former is regarded as the domain of the doctor and the latter that of the philosopher. A crucial text for the elaboration of the parallel is Plato's Gorgias, which uses the example of medicine, both to assert the status and value of true arts or sciences in contradistinction to false ones, and to indicate the existence of an equivalent or higher expertise concerned with the goods of the soul - the domain of justice, in which the expert will be the philosopher. Galen engages closely with that text, quoting from it and following its argument in detail, in his other important work on the definition of and proper approach to health, Thrasybulus. ${ }^{16}$ He finds support here for his claims for the elevated status and scientific nature of the art of medicine. Yet, at the same time, this is a text which tends to point to a clear distinction between the domains of health of soul and health of body.

14 See Singer (1992); Gundert (2000); Thumiger (2013) and (2017).

15 One may point to the presence of 'psychological' and 'physical' symptoms alongside each other, for example in lists of symptoms in the Epidemics (see further the literature cited in the previous note). And see n. 24 below on the (unacknowledged) importance to Galen of the Hippocratic text Regimen.

16 See esp. Thras. $34-36$ (V.872-76 K. = 81-83 Helmreich). 
In this context it is worth considering Plato's own direct contributions to the discussion of holism. Two texts are of particular relevance: Charmides (on which see further chapter 8 below) and Phaedrus. The argument of Charmides (156b-57a) proceeds by a progressive expansion of the 'whole' that is relevant to the clinical context. First, it is suggested that the doctor curing an eye complaint must not just know about the eyes, but also about the whole head; then, that he must in fact know about the whole body; finally, it is proposed that understanding of the whole body will be incomplete or inadequate without attention to the soul too, such attention being, in fact the starting-point for successful medicine. Here, then, the soul - body unity is the relevant 'whole' ( $\tau 00$ ö $\lambda \circ 0,156 \mathrm{e}$ ) which medicine must address. In Phaedrus, meanwhile, Socrates praises 'Hippocrates' for, precisely, a kind of holism, that is to say an insistence on investigation into the nature of the whole. Unfortunately, it is not clear, and certainly not agreed by modern scholarship, precisely which 'whole' is in question here. The argument at this point has developed (again) from a parallelism between the domains of soul and body (27ob); it is then asserted that 'it is impossible to understand the nature of the soul without the nature of the whole' (270c). Is it knowledge of the soul in its entirety that is meant, or knowledge of the entire soul-body unity, or indeed knowledge of the whole cosmos? What is clear, however, is that Plato is asserting - and attributing to Hippocrates - the view that proper scientific knowledge must proceed from an understanding of (followed by appropriate subdivision of) the relevant 'whole' in question.

Galen responds directly to this passage from Phaedrus, though in the context of scientific method rather than that of the soul-body relationship: he takes it to support his own views on correct procedure in the study of nature. ${ }^{17}$ His response to Plato's statement of holism understood specifically in relation to the soul-body complex is perhaps less clear, or at least less explicit. We might wish to say that the holism of Charmides is tendentially reversed by that of Galen's The Soul's Dependence on the Body. In the former, medical expertise seems ultimately to be subsumed under that of the philosopher; in the latter, it is the doctor who turns out to have the understanding which is most relevant, also in ethical contexts. ${ }^{18}$

17 E.g. in his Commentary on Hippocrates' Nature of the Human Being $(H N H) 1(\mathrm{XV} .4-5 \mathrm{~K} .=$ 4-5 Mewaldt). Interestingly in relation to the Charmides argument, Galen explicitly attacks (for example in Parts of Medicine) doctors with a specialism confined to one particular part of the body. That attack is doubtless to be understood partially in socio-medical terms - Galen the educated, encyclopaedic intellectual asserting his superiority over mere artisan practitioners.

18 It is a complicating factor in Galen's case that he wishes at times to present himself also as a philosopher. So, the demarcation of a distinct medical and philosophical expertise 
Yet, as already suggested, neither of those is the whole story, since both Plato and Galen operate in many of their discussions with a clear division and parallelism between the two areas of expertise.

\subsection{Areas of Competence: Doctor versus Philosopher?}

These complexities in the relationship between the Platonic-Galenic medical-philosophical discourse lead us on to another point. The doctor, Galen says, is interested in the health of the soul, and should therefore have a wide range of musical and cultural knowledge:

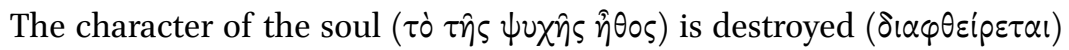
by bad habits ( $\mu \circ \chi \theta \eta \rho \hat{\omega} \nu \varepsilon \dot{\varepsilon}(\sigma \mu \hat{\omega} v)$ in food, drink, physical exercise, things watched and heard, and music as a whole. Indeed, the person who undertakes the art of health should be experienced in all these, and should not think that it is only the business of the philosopher to shape the character of the soul ( $\pi \lambda \dot{\alpha} \tau \tau \varepsilon \nu \hat{\eta} \theta \circ \varsigma \psi \cup \chi \hat{\eta} \varsigma)$; but rather his because of something greater,

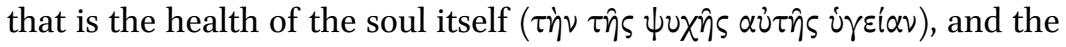
doctor's for the sake of the body's not being dragged with it into sickness. GALEN, San. Tu. 1.8 (VI.4O K. = 19 Koch)

In the doctor's case, then, such knowledge has an ultimately bodily aim. You might have thought that such things as music, entertainment and performance arts would be beyond the doctor's ken. This is not the case. Nor is it the case, however, that such knowledge belongs, properly speaking, in the doctor's domain. The doctor's expertise in 'soul' matters is here an instrumental one: he must interest himself in them because of their impact on the health of the body. It is the philosopher who would be expected to have an interest in the soul 'for the sake of something' higher - that is to say, presumably, for the sake of the soul in its own right, for its moral or ethical health.

But this Platonic parallelism has very particular consequences in the later philosophical-medical tradition: the idea that doctors can and should interest themselves in philosophical matters turns out to be a highly controversial one, reflecting an ongoing dispute over competence in the Graeco-Roman intellectual and healthcare world. It seems probable, as Sean Coughlin suggests, that Athenaeus of Attalia was a pivotal figure in this history, drawing on both the medical tradition and Platonic discourse, prefiguring, possibly indeed

would not deprive Galen of his competence: he may have two distinct areas of competence, in two different personas. 
influencing, Galen's synthetic, Platonist-cum-medical approach. ${ }^{19}$ There were both doctors who believed that doctors should not delve into philosophy (apparently Soranus was also one of these ${ }^{20}$ ) and philosophers who rejected physical health as an appropriate topic for their debates. A near-contemporary of Galen's, Plutarch, gives evidence of this debate.

zeUXIPPUS ... in medicine that man [Glaucus] is, as Homer has it, 'one who is worth many others', yet he is hostile towards philosophy ... He was just attacking us, proclaiming that ... we were responsible for a great ... confusion, daring to discourse on the healthy daily regime ( For he stated that the border between philosophers and doctors should be as distinct as that between Mysians and Phrygians.

moschion. And yet I would gladly have heard this and the other discussions.

zeuxippus. Well, you are a philosopher by nature, Moschion, and do not object to a philosopher who is interested in medicine; indeed, you get angry with one who thinks it more appropriate to be seen laying claim to the knowledge of geometry, dialectic and music than wanting to learn 'that which has been here established as good or as bad', for the body.

Plutarch, Precepts on Health, Moralia 122b-e

Plutarch here presents us (a) with the figure of such an anti-philosophical doctor, Glaucus, who believes in a strong separation between medicine and philosophy, (b) with the notion that certain philosophers confine their interests to geometry and dialectic rather than bodily health, but also (c) with the actual characters of the dialogue, Zeuxippus and Moschion, respectively a philosopher who does take a strong interest in matters of health and a doctor who is 'a philosopher' by nature - and, of course, with the notion of a fruitful conversation between them.

Both within medicine and within philosophy, then, one could have an argument, not just on that conventional bone of contention, the relationship of soul and body, but also as to how holistic one's own discipline actually is or should be. Should the philosopher interest himself to know about dietary interventions, because they may have an influence on the soul - or, if you like, the person as a whole? Is it appropriate, or arrogant and carpet-bagging, of

\footnotetext{
19 See Coughlin (2018).

20 Soranus, Gynaecology 2.57.2-3 (93 Ilberg), cited by Coughlin (2018) 112. Competence conflicts between medicine and philosophy are explored further, especially in the context of Stoic authors and Caelius Aurelianus, by Ahonen (2018); cf. Polito (2016).
} 
the doctor to say things about the soul or mind, the traditional domain of the philosopher?

\subsection{Mental Illness: Causal and Therapeutic Complexity}

Within Galen, we have been considering the question of mind-body holism mainly in relation to the question of the pathe psychess and how these (and the philosophical discourse around them) interact with the body (and with medical approaches to it). We also briefly considered Galen's approach to the medical psychic impairments.

We should consider, then, how Galen's approach in this latter context here may contrast with that of his contemporaries or near-contemporaries. For while Galen's clinical approach to the medical psychic impairments is largely based on physical interventions - diet, sleep, exercise, and so on in milder cases; drugs and blood-letting in more severe ones - there are also somewhat different clinical tendencies within the medical culture of the period - tendencies which seem to take account of or interact with the patient in a broader sense than simply in terms of aberrations in bodily mixture, and might in that sense be considered holistic in ways which Galen's clinical practice is not.

The encyclopaedist and medical author Celsus, for example, having made a distinction between different varieties of insania, suggests a number of interventions which involve attention to the individualities of patient experience, and to the patient's environment. Advice is given as to the extent to which a deranged patient is to be agreed with or indulged, as opposed to corrected; techniques are suggested to engage the patient's interest; suggestions are made for varieties of music as story-telling, as well as for the creation of an appropriate environment, especially in terms of light and darkness. ${ }^{21}$

And similar therapeutic approaches can be found in Aretaeus, Caelius Aurelianus and Rufus. Aretaeus advises peace and quiet, and a simple physical environment, to counteract the over-excited mental state of phrenitis, and gives a reverse kind of prescription for the depressed state of lèthargos. Caelius offers detailed prescriptions, in terms of the appropriate kinds of language and intellectual interaction (including reading aloud to the patient with deliberate errors; theatrical entertainments; vocal exercises) for different levels or phases of furor (equivalent to Greek mania). ${ }^{22}$

21 Celsus 3.18 (123-26 Marx), discussed by Thumiger and Singer (2018) 11-14.

22 See Aretaeus 5.1 (91-92 Hude) and 5.2 (esp. 98 Hude); Caelius, Acute Diseases 1.11.98-99 (76 Bendz); 1.11.8o-82 (66-68 Bendz); Chronic Diseases 1.5.156-57 (522-24 Bendz) and 1.5.162-67 (562-68 Bendz); and cf. 1.5.175-79 (534-36 Bendz). 
It is probably important not to exaggerate the differences here, or the prominence of this cognitive or interactive model: passages such as those just considered remain, within the texts of Celsus, Caelius and Aretaeus, the exception rather than the norm. Yet is fair to say that, at points at least, a therapeutic approach is suggested which is interestingly different from that based entirely on dietary or pharmaceutical interventions.

\subsection{Summary}

In summary we may say that (a)-type holism exists at least in the sense that, in certain important diagnostic and clinical contexts, soul and body are inextricably interconnected; but that there is a potential conflict between this 'interconnectedness' and various statements of mind-body parallelism or dualism - even if this may in some contexts be understood, as I have suggested said, as a merely 'pragmatic dualism.' There is, also, a perceived tension or conflict as to how holistic - or, alternatively, dualistically divided, the disciplines of medicine and philosophy are, or should be. Finally, the extent to which soul and body attract different types of clinical treatment is different in different medical authors of the imperial period.

\section{3}

\section{Whole-Body Holism}

\subsection{Galenic Medicine: Whole Body or Affected Part?}

I turn then to my second main category, 'whole-body holism.' The following passage gives a brief encapsulation ${ }^{23}$ of the way in which human health is understood in terms of a state of the body as a whole, in turn understood ultimately as a balance of the fundamental qualities, hot, wet, cold and dry which compose it.

... while the health of the uniform ( $\delta \mu \circ 10 \mu \varepsilon \rho \omega \nu)$ parts, as they are called,

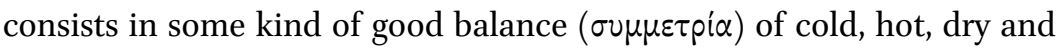
wet, that of the organic (opravix $\omega v$ ) parts is brought about from the com-

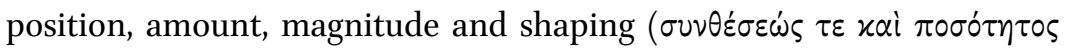

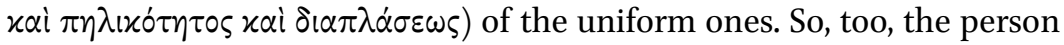
who is capable of preserving these will be the good preserver of health.

GALEN, San. Tu. 1.1 (VI.1 K. = 3 Koch)

23 Further texts of particular relevance here are Causes of Diseases and Distinctions in Diseases, which - with some elaboration and some variations - offer a fundamentally similar account of the levels of analysis within the body. 
Though the specifics of the model (the division into the levels of organic and uniform parts, the underlying conception of mixture) are Galenic, the notion that health and disease consist in some kind of balance or imbalance of the fundamental constituents of the body again has clear Hippocratic ancestry; indeed, the notion is, in different forms, pervasive in ancient medical thought. ${ }^{24}$ To give just two central examples of Galenic texts which seem to foreground this (b)-type holism, both Matters of Health and Mixtures prominently feature the notion of overall states of the body as explanations for individual patient characteristics and pathologies. So too, a wide range of Hippocratic texts (prominently e.g. The Nature of the Human Being, The Sacred Disease, Affections, Regimen) present some combination as fluids as the fundamental constituents of the human body and/or as responsible for health and disease. $^{25}$

But how do such apparently holistic notions fit with the importance of determining the locus affectus - the precise organ or place in a body which is affected, or which is the underlying cause of a condition? ${ }^{26}$ The latter notion is also one which Galen insists on and elaborates at considerable length, not least (unsurprisingly) in his work entitled Affected Places: here, it is crucial to diagnosis and treatment to identify, not just a general, overall state of the body, but the location or origin of the ailment.

One must always start with the organ of the damaged activity $(\beta \varepsilon \beta \lambda \alpha \mu \mu \varepsilon \dot{v} \eta \varsigma$

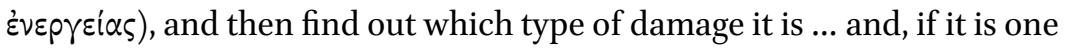
that has already become established, whether the effective cause of the

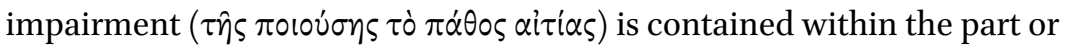
is passing through it ...

24 The Anonymus Londinensis offers a more precise doxographical distinction, between texts that rely on a theory of elements and those that rely on a theory of residues. For the prevalence of theories of balance in ancient theories of health - and also for the specific similarity of Galen's views in this area to those of the Hippocratic Regimen, even though he does not explicitly acknowledge it - see Grimaudo (2008).

25 So, for example, in Mixtures (Temp.) 2.6, the progress from childhood to old age is understood as a gradual process of cooling and drying, therefore the old are prone to 'cold diseases'; different overall disease-types, understood in terms of the model hot-cold-wet-dry, derive from environmental conditions that have those qualities (cf. Commentary on Aphorisms (Hipp. Aph.) 6.67 (XVIIIA.78-79 K.), for a patient with a yearly onset of melancholy); and an overall process of drying-plus-heating is a predisposing cause of fever. For this last phenomenon, in addition to the passages cited from Matters of Health, cf. Causes of Diseases (Caus. Morb.) 2 (VII.4 K.), and the passages gathered in the Appendix of Singer (2017).

26 On the significance, and disputed nature, of this concept in ancient medical thought, see also McDonald (2011). 
A further distinction we should make is between impairments $(\pi \dot{\alpha} \theta \eta)$ which arise through sympathy with another part and those which arise by 'idiopathy' ...

GALEN, Loc. Aff. 1.2 (VIII.22 K. = 252 Gärtner); 1.3 (VIII.3o K. = 26o Gärtner)

As seen from these quotations, Galen does more than just emphasize the importance of bodily location. He makes precise distinctions in terms of original or primary location and the secondarily or sympathetically affected part - distinctions which will have crucial consequences for treatment.

There are, moreover, important diagnostic distinctions to be made within particular bodily locations, between the solid structures and the fluids or residues that arise within them. This can be seen from the following two passages, the first designed to correct a common misconception to do with old age, the second arising in the context of a fascinating Galenic attempt to make precise aetiological distinctions within the pathology of the brain and of mental disorder.

... some well-reputed doctors ... maintain that old age is wet ... deceived by the quantity of the residues ( $\pi \varepsilon p i \tau \tau \omega \mu \dot{\alpha} \tau \omega \nu)$. For their eyes water, their noses fill with mucus, and a large amount of saliva gathers ... their lungs, too, are full of this kind of fluid ( $\chi \cup \mu \circ \hat{)}$... None of these things, however, contradicts the proposition that the bodies of the old are dry.

GALEN, Temp. 2.2 (I.580 K. = 45 Helmreich, trans. Singer and van der Eijk, p. 110)

... each disposition ( $\delta(\alpha \theta \varepsilon \dot{\varepsilon} \sigma \omega \varsigma)$, too, will have two versions, one arising from the wet or dry fluids ( $\chi \cup \mu \circ i \varsigma)$, the other from the bodies themselves, in the case where the solid bodies reach the same state of bad-mixture

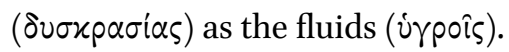

GALEN, Loc. Aff. 3.6 (VIII.163 K.)

\subsection{Galen versus the Others}

It is not only that Galen insists on this kind of analysis; such an analysis also provides a bone of contention between him and rival ancient physicians, in particular the Methodists but also others who insist, rather, on talking of states of the whole body and not of the part affected. In the following passages we may observe such arguments advanced by Methodists both in propria persona and through the lens of Galen's criticism. (A much fuller and more nuanced account of the Methodists' views in this area is given by David Leith, in chapter 5 above.) 
Soranus ... states that the whole body is troubled by the ailment (passione) [sc. peripneumonia], but the lung more violently ... [Such an enquiry] is useless from the point of view of cure, since this is in no way compromised by a lack of precise knowledge of locations, for it is the whole body which we feel to suffer. Nor should the nature of the remedies be altered in relation to the place affected; this should remain the same as long as the disease itself remains.

Caelius aurelianus, Acute Diseases 2.28.147-48 (232 Bendz)

[In insania] the entire nervous apparatus (nervositas) suffers (patitur) ... but the head suffers more (magis) ...

Caelius aurelianus, Chronic Diseases 1.5.152 (520 Bendz)

[A Methodist:] Why should one consider the parts of the body? Are these not valueless for the indication of treatment? ... Since the nature of the part does not in any way alter the mode of treatment ... consideration of the part will, obviously, be pointless.

GALEN, Sects for Beginners (SI) 7 (I.86-87 K. = 18 Helmreich)

The Methodists are well known to have reduced all illnesses to certain commonalities (koinotētes), understood in terms of constriction or looseness. Evidence such as the above suggests that they went further and insisted on these commonalities as states of the whole body rather than of specific locations. Soranus (first century BCE/CE), or Caelius Aurelianus (fifth century CE), is prepared to admit of a part which suffers more, or more violently. But at the same time there is a resistance to the notion of the locus affectus as such, and an insistence that even the notion of a part which patitur magis is irrelevant to treatment. This insistence may seem odds with another well-known feature of Methodist medicine, namely the presentation of diseases, in the texts, in a 'head-to-toe' order. The Methodist view appears to be that local manifestations of an illness are relevant features, of value for diagnosis, but that all diseases are nevertheless diseases of the whole body, and must be treated accordingly.

Another view of interest in this connection is that of Celsus. By contrast with the Methodists, Celsus does not insist on the non-local nature of diseases in general. He does, however, define a specific category of diseases as being, precisely, diseases of the body as a whole, rather than arising in particular parts. ${ }^{27}$

27 For further discussion of Celsus' diagnostic divisions, see now Thumiger and Singer (2018) $7^{-15}$. 
I shall divide all [sc. diseases] into those which appear to subsist in the body as a whole (in totis corporibus consistere videntur) and those which arise in particular parts (oriuntur in partibus).

CELSUS 3.1 (101 Marx)

For Celsus, then, not all diseases, but an important subset of them, are without specific location. This subset includes both fevers - that most prominent, indeed almost omnipresent, entity in ancient medicine - and mental aberrations, ailments of the soul.

An interesting consideration here is that the notion that either mental aberrations of a certain kind or fevers might be defined as diseases of the whole body is one that Galen could in principle largely have agreed with. In the case of the medical psychic impairments, especially those involving paralysis or lethargy, the condition as Galen describes it certainly has a powerful effect on the whole body. ${ }^{28}$ And with fevers too we seem to have a condition which involves the whole body: he tells us, indeed, that the cause of fever is that a pathological level of heat has become extended through the body as a whole. ${ }^{29}$ It is striking, then, that he nevertheless does not explicitly conceptualize, as Celsus does (and as Caelius and the Methodists do in a much more sweeping way) the notion of diseases, or of certain diseases, being 'of the whole body'

In any case, we have seen clear limitations to Galenic (b)-type holism: in certain contexts, at least, it is important to insist on precise location against opposing notions of diseases as belonging to the body as a whole. And - to touch again briefly on the evaluative point - we may very well find this limitation a positive thing: it would surely be difficult to deny that, in at least some medical contexts, precise knowledge of the location and physiology involved in a disease is, to put it at its mildest, something worth having. On the other hand, to what extent does Galen really operate such a precise, local analysis? It is, perhaps, enlightening to consider the polemical or competitive context. To what end does Galen spend so long in Affected Places and elsewhere insisting on detailed knowledge of internal parts, of physiology, of the locus affectus and how much difference does it make in practice?

Let us consider one particular case upon which Galen expends a lot of energy, both in Affected Places and elsewhere, namely the importance of understanding that the brain is the location of mental or psychological

28 See e.g. Symp. Diff. (VII.58-59 K. = 221-22 Gundert), with the discussion of Singer (2018) 388-40.

29 Caus. Morb. 2 (VII.4 K.). 
aberrations - those, precisely, of the hègemonikon or leading-faculty of the soul. Galen recurs to this theme often and at considerable length.

The fact that all ailments of the leading activities ( $\tau \dot{\alpha} \tau \hat{\omega} \nu \dot{\eta} \gamma \varepsilon \mu o v i x \hat{\omega} \nu$ $\dot{\varepsilon} \varepsilon \varepsilon \gamma \varepsilon \mid \hat{\omega} \nu \pi \dot{\alpha} \theta \eta$ ) arise in the brain is agreed by all doctors, as long as they do not think one thing in their soul but say another, as the result of the argumentative compulsion of a sect ... such argumentativeness ... is unforgiveable amongst those with long experience in medical matters. For they bathe the head in all cases of infirmity arising from sleeplessness, as also in all cases of delirium, phrenitis and lèthargos. Archigenes applies medicaments to the head in cases of damage to the memory, too ...

GALEN, Loc. Aff. 3.7 (VIII.166-67 K.)

How crazy and incoherent, cries Galen, are his rival physicians, those who claim in theory to believe that the seat of the soul is the heart, but then when an ailment of the soul comes along apply their remedies to the head! Archigenes is a particular butt of this polemic. Why on earth do he and others apply remedies - embrocations, in particular - to the head if the head is not the seat of the illness in question? And of course we may very well feel that Galen - even if he does undoubtedly over-egg his pudding - is on pretty solid ground here. Yet it is at least arguable, as Orly Lewis has suggested, that it is Galen who is distorting the picture: that he is representing a whole repertory of traditional remedies as 'directed towards the brain', which are in fact better understood as, precisely, part of a (b)-type holistic approach which sought to heat or cool the whole body. ${ }^{30}$ It seems, moreover, highly probable that he is borrowing strongly from precisely those physicians with whom he claims to have a strong theoretical opposition. That is to say, he may very well be strongly indebted to Archigenes for the actual range and choice of remedies used. That, of course, does not in itself affect the validity or invalidity of his claim; but one should at least consider the counter-argument that the fact that some (though by no means all) remedies were applied to the head in such cases need not entail any particular view on the location of the hègemonikon - either on Galen's part or on that of his rivals. The underlying principle might be, precisely, one which views psychological aberration and its treatment as implicating the body as a whole.

But let us consider the Galenic approach more broadly. We have seen evidence of his insistence on the identification of the locus affectus, and on a distinction between solid structures and fluids or residues. Yet, again, when 
we come to practice, most of Galen's actual interventions - diet, drugs, venesection - seem to be addressed towards an alteration of the state of the body as a whole. One must of course make certain exceptions, e.g. for the treatment of wounds; and one must consider seriously some of the specifications made in Affected Places already observed. Still, one is left with a suspicion that some of Galen's most precise specifications of the part of the body affected, and the aetiology by which this affects other parts or structures, are not followed up in very great detail or may not have very profound consequences for actual therapy. The suspicion may, indeed, arise that such specifications are motivated at least partly by polemical rather than practical considerations that is to say, by Galen's desire to distinguish himself ideologically from the Methodists and, more generally, to assert the superior level of his own detailed knowledge of the internal structures and functioning of the human body.

Certainly, Galen insists that one must tailor interventions specifically to the individual nature, with particular attention to a person's natural endowments, previous habits, age, etc.; and all these factors receive a great deal of attention in Matters of Health. But considerations arising from distinctions between different parts or functions within the body receive much less. The following passage on old age summarizes Galen's approach through much of this work, and indeed elsewhere.

One should, in all cases, attempt correction through the opposing imbalance. Age, itself, is cold and dry ... Its correction takes place through those things which moisten and heat, such as hot baths ... the drinking of wine ...

GALEN, San. Tu. 5.3 (VI.319 K. = 141 Koch)

It seems to me that this approach - essentially consistent with our (b)-type holism - is fairly representative of much of Galen's practice.

\subsection{Further Aspects of Galenic Holism: Diagnosis, Fever, Pulse}

A little should be said concerning the further sub-distinction, suggested at the outset, between (b1)- and (b2)-type holism. In particular, one might want to argue for (b1)-type holism - the strong diagnostic relevance of features observed throughout the whole body - while holding to a much less holistic view with regard to the location and treatment of a disease. Two things seem particularly relevant, here, in relation to Galen. One is that he certainly would wish to claim - again in a way strongly indebted to the Hippocratic tradition that a whole range of factors, observable in different parts of the body, and by 
different senses, are potentially relevant to diagnosis. The extended account of the facies Hippocratica and other fatal signs in the Commentary on Hippocrates' Prognostic, combining the Hippocratic tradition with Galen's own claims to both precise and wide-ranging observation, provides a particularly pertinent, and rich, example. ${ }^{31}$ The other is to consider the centrality of the pulse, as a diagnostic and prognostic tool, on the one hand, and on the other of fever as a disease category, within Galen's medical thought and practice.

The pulse is a diagnostic indicator that both belongs to the whole body - it can in principle be taken anywhere in the body, as Galen himself emphasizes and reveals information about the state of the body as a whole. Now, it is of course true that certain specific types of pulse, taken in conjunction with other diagnostic indicators, will help identify particular, localized ailments. But it is also true that fever (as the object of diagnosis) is almost as prominent in Galen as pulse (as the tool of diagnosis): the two may in a sense be seen as counterparts. So, for example, in that work which functions as both advertisement and summary by Galen of his own clinical practice, Prognosis, it is above all - leaving aside considerations 'external' to the art $^{32}$ - the pulse which Galen presents as the focus of his diagnostic skill. And, in terms of diseases described, it is - leaving aside certain psychogenic pathological states - fever that appears as the central diagnostic category. This twin dominance of pulse and fever is then further reinforced by the particular works of his own to which Galen points us in this work: the series of works on the pulse, and the treatises Crises, Critical Days and Distinct Types of Fever. ${ }^{33}$ Between them these explicate the diagnostic or semiotic 'science' of which he has, in Prognosis, given practical exemplification.

And indeed, the above groups of works occupy a central place in Galen's diagnostic and clinical output. Given that the pulse is a diagnostic indicator

31 Hipp. Prog. 1.5-42 (XVIIIB.22-109 K. $=209-58$ Heeg). Especially relevant here are the fact that the specific bodily features observed in the face enable one to infer facts about the state of the body as a whole; and the fact that other signs, arising in different parts of the body (e.g. sleeplessness, loose bowels, hunger, XVIIIB.32 K. = 214 Heeg; the pulse, XVIIIB.38 K. = 217 Heeg; delirious hallucinations, XVIIIB.71-75 K. = 236-38 Heeg; respiration, XVIIIB. $76-77 \mathrm{~K} .=238-39$ Heeg) are brought in to confirm or clarify the diagnosis arising from observation of the face. Indeed, Galen explicitly emphasizes the connection between signs from the face and those from the rest of the body at XVIIIB. $55^{-} 5^{6} \mathrm{~K}$. = 227 Heeg.

32 Galen's own term ( $\left.{ }^{2} \xi \omega \theta \varepsilon v\right)$ at Prognosis by the Pulse (Praes. Puls.) 1.1 (IX.216 к.).

33 These latter works are mentioned as crucial at Praen. 9-10 (XIV.651-52 K. $=120$ Nutton and XIV.657 K. = 126 Nutton) and ch. 12 (XIV.664 K. = 132 Nutton); the pulse works at 14 (XIV.671 K. $=138-40$ Nutton). 
of the whole-body state, and that fevers are, as we have suggested, whole-body illnesses, this emphasis in Galen's writing again supports a strong sense of both (2a)- and (2b)-type holism.

\subsection{Summary}

Here again, it would be difficult to deny that a somewhat complex picture has emerged. Undoubtedly, certain other doctors or medical schools emphasize the whole-body approach to health and disease more strongly and more explicitly than does Galen; and in some contexts that represents an explicit point on which he attacks them. It is also true that - again in certain contexts - the locus affectus is of central importance to Galen's argument. But it also seems to be true that we lose much if we ignore the polemical aspect of that argument; and that, in terms of actual interventions and dietary recommendations, what Galen offers tends toward a model in which he to quite a large extent conceptualizes health, as well as disease, diagnosis and treatment, in relation to the body as a whole.

\section{One-with-the-Cosmos Holism}

We as human beings are part of, and composed of the same fundamental elements as, the world around us. In a sense, of course, this is obvious. But Galenic (like most varieties of Hippocratic) medicine arguably makes the connection closer and more palpable. It does this in two ways especially. First, it emphasizes the essential qualitative identity of our bodies with simpler organisms and other objects in the outside world: both within our bodies and outside them, the hot, cold, wet and dry are not only the ultimate, but also very frequently the clinically most relevant, constituents. The transition from talk of the heat or dryness of our bodies to talk of those same qualities in plants, meats, drugs, etc., is - as we have already observed in Mixtures and Matters of Health, to which could be added The Properties of Foodstuffs - a seamless one. Secondly, it emphasizes the fundamental importance to health and ill-health of the immediate environment, in the sense of the seasons and the ambient air.

So much seems clear; and this embeddedness of human natures within their biological and meteorological environment undoubtedly provides one of the stronger senses in which the term 'holistic' may reasonably be applied to the ancient medical discourse.

Grander, or more elevated, accounts of the sense in which we are 'one with the cosmos' are offered by the philosophical and ethical, rather than strictly medical, tradition. For example, the notion of our fundamental oneness with 
nature, our connectedness with the cosmos, is a key feature of Stoic thought. This can be understood both in terms of our physical or environmental nature (we function within and should take account of the larger ecological entity) and our nature as rational beings (our rational nature provides a connection with the universe as a whole, which is to be understood as a rationally ordered entity). ${ }^{34}$

Such considerations may at first sight seem less relevant to our enquiry. But in at least one context Galen does want to insist strongly on our connectedness with the universe, conceived in terms of a higher or transcendent rationality:

What part of the cosmos could be of less worth than the earthly one? And yet even here, some intelligence arrives from the heavenly bodies bodies whose contemplation leads one at once to wonder at the beauty of their substance, of the sun ... of the moon ... of the stars.... just as the substance (ovं $\left.\sigma^{\prime} \alpha\right)$ of their bodies is purer ( $\left.\kappa \alpha \theta \varepsilon p \omega \tau \dot{\varepsilon} \rho \alpha\right)$, there exists an intelligence which is to precisely that same degree better and more complete. When we see that in slime, in mud, in marshes, or in rotting plants and fruits, there nonetheless arise animals which provide a wonderful

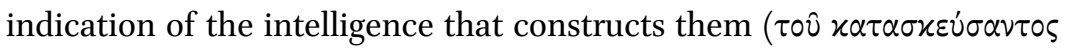
$\alpha \dot{\tau} \tau \dot{\alpha} v \circ \hat{v})$, what must one think is the case of the heavenly bodies? ... it seems to me that a considerable intelligence is extended (oỉx $\partial \lambda i^{\prime} \gamma \circ \tau, \varsigma$

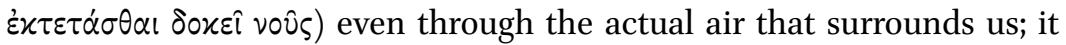
would not otherwise be able by nature to partake of the sun's ray nor of its power.

GALEN, On the Function of the Parts of the Body (UP) 17.1 (IV.358-6o к. = ii.446-47 Helmreich)

Galen is here talking in terms which have strong Platonist echoes, although there is, certainly, a distinct lack of precision in the theory as expounded here. ${ }^{35}$

34 Recent scholarship on Stoicism has emphasized these features both as central elements of Stoicism and as ones which can be attractively interpreted within a twenty-first century worldview. See e.g. Gill (2014), as well as https://modernstoicism.com/\#_ednref25.

35 Fundamental to the study of this text is Frede (2003), who, while admitting the 'tantalizingly vague' (111) nature of Galen's remarks, also explores in depth their connections with other late antique philosophical and scientific views, and shows how Galen is here asserting the all-pervasive explanatory power of the sun in the physical universe, as well as its causal relationship with the Demiurgic intellect, on the one hand, and the composition of bodies and their fundamental elements, on the other. (Some aspects of Galen's relationship with Platonists of his time are also discussed by Singer (2014).) A broader point of relevance to our argument, though it cannot be considered further here, is the sense in which Neoplatonist thought may itself be understood as holistic (rather than, as 
But it seems to me that there is a profound sense in which what is in play here is another form of holism - one again belonging within our type (c), and one to which Galen, even if he is unclear about the metaphysical detail, profoundly subscribes. That is, the sense in which our intelligence, or indeed the intelligence of any being on the earth - to the extent that it has intelligence connects us with the stars, with the divine intelligence. That may not be something that Galen, or any medical author, is prepared to elaborate in detail; but some such account is, in fact, central simultaneously to Galen's teleological and to his physical world view.

Moreover, it is possible to bring things down to earth a little. There is, as we have already seen, (c)-type holism in the sense of the fundamental continuity between our own, human natures and that of the rest of the natural world. But there is a further point, too. Galen understands human beings as belonging, in both physical and epistemological terms, at the centre of the universe. It is not just that we represent a sort of optimal or central case of the mixture which also accounts for the composition of all things in the natural world. It is simultaneously the case that this central position of human beings within the cosmos has consequences for the role of our rationality within the universe. Human beings are ideally constructed and positioned to observe and evaluate everything else in the natural world. ${ }^{36}$

So, in fact, a proper understanding of our cosmic nature - of the way in which both our rationality and our physicality are connected with those of the universe as a whole - is central, not just to Galen's theological views but also to his scientific project. It is some such account - a cosmically holistic account, if you like - which explains how it is that we are able to discuss these matters rationally in the first place; to engage successfully in the project of observation, analysis and diagnosis; to conceptualize and take care of our health.

\section{Acknowledgments}

I am grateful to Chiara Thumiger for the invitation to participate in the conference 'Ancient Holisms' in London in 2017, as well as to the participants at that event for helpful and congenial interaction. I also express my gratitude to the

it typically is, dualistic), because of the fundamental understanding of Intellect and Soul as explanatory principles that pervade the entire cosmos, including the biological and human world.

36 For Galen's assertion of both points, see esp. Temp. 1.9 (I.563-65 K. $=34-35$ Helmreich), with the notes of Singer and van der Eijk (2018) ad loc. 
Wellcome Trust, by which I was funded for the research project within which the present paper took shape.

\section{Bibliography}

Adamson, P., Hansberger, R. and Wilberding, J. (eds.) Philosophical Themes in Galen. Bulletin of the Institute of Classical Studies Supplement 114. London: Institute of Classical Studies (2014).

Ahonen, M. 'Making the Distinction: the Stoic View of Mental Illness.' In Mental Illness in Ancient Medicine: from Celsus to Paul of Aegina, Studies in Ancient Medicine 5o, ed. C. Thumiger and P. N. Singer. Leiden: Brill (2018) 343-62.

Barnes, J., J. Jouanna and V. Barras (eds.) Galien et la philosophie: huit exposés suivis de discussions. Entretiens sur l'antiquité classique 49. Vandoeuvres: Fondation Hardt (2003).

Coughlin, S. 'Athenaeus of Attalia on the Psychological Causes of Bodily Health.' In Mental Illness in Ancient Medicine: from Celsus to Paul of Aegina. Studies in Ancient Medicine 5o, ed. C. Thumiger and P. N. Singer. Leiden: Brill (2018) 109-42.

Devinant, J. 'Mental Disorders and Psychological Suffering in Galen's Cases.' In Mental Illness in Ancient Medicine: from Celsus to Paul of Aegina, Studies in Ancient Medicine 5o, ed. C. Thumiger and P. N. Singer. Leiden: Brill (2018) 198-221.

Donini, P.-L. 'Psychology'. In The Cambridge Companion to Galen, ed. R. J. Hankinson. Cambridge: Cambridge University Press (2008) 184-209.

Frede, M. 'Galen's Theology.' In Galien et la philosophie: huit exposés suivis de discussions. Entretiens sur l'antiquité classique 49, ed. J. Barnes, J. Jouanna and V. Barras. Vandoeuvres: Fondation Hardt (2003) 73-129.

Gill, C. Naturalistic Psychology in Galen and Stoicism. Oxford: Oxford University Press (2010).

Gill, C. 'Introduction.' In Epictetus: The Discourses. Trans. R. Hard. Oxford: Oxford University Press (2014).

Grimaudo, S. Difendere la Salute: Igiene e Disciplina del Soggetto nel De Sanitate Tuenda di Galeno. Elenchos: A Collection of Texts and Studies on Ancient Philosophy 49. Palermo: Bibliopolis (2008).

Gundert, B. 'Soma and Pysche in Hippocratic Medicine.' In Psyche and Soma:Physicians and Metaphysicians on the Mind-Body Problem from Antiquity to Enlightenment, ed. J. P. Wright and P. Potter. Oxford: Oxford University Press (2000) $13-35$.

Hankinson, R. J. 'Galen's Anatomy of the Soul.' Phronesis, 36 (1991a) 197-233.

Hankinson, R. J. 'Greek Medical Models of Mind.' In Psychology, Companions to Ancient Thought 2, ed. S. Everson. Cambridge: Cambridge University Press (1991b) 194-217. 
Hankinson, R. J. 'Actions and Passions: Affection, Emotion and Moral Self-Management in Galen's Philosophical Psychology.' In Passions and Perceptions: Studies in Hellenistic Philosophy of Mind, ed. J. Brunschwig and M. Nussbaum. Cambridge: Cambridge University Press (1993) 184-222.

Hankinson, R. J. 'Body and Soul in Galen.' In Common to Body and Soul: Philosophical Approaches to Explaining Living Behaviour in Greco-Roman Antiquity, ed. R. A. H. King. Berlin: De Gruyter (2006) 232-58.

Hankinson, R. J. (ed.) The Cambridge Companion to Galen. Cambridge: Cambridge University Press (2008).

Havrda, M. 'Body and Cosmos in Galen's Account of the Soul.' Phronesis, 62 (2017) $69-89$.

Johnston, I. (trans. with introduction) Galen on Diseases and Symptoms. Cambridge: Cambridge University Press (2006).

Julião, R. 'Galen on Memory, Forgetting and Memory Loss.' In Mental Illness in Ancient Medicine: from Celsus to Paul of Aegina, Studies in Ancient Medicine 50, ed. C. Thumiger and P. N. Singer. Leiden: Brill (2018) 222-44.

Kaufman, D. H. 'Galen on the Therapy of Distress and the Limits of Emotional Therapy.' Oxford Studies in Ancient Philosophy, 47 (2014) 275-96.

Lewis, O. 'Archigenes of Apamea's Treatment of Mental Diseases.' In Mental Illness in Ancient Medicine: from Celsus to Paul of Aegina. Studies in Ancient Medicine 5o, ed. C. Thumiger and P. N. Singer. Leiden: Brill (2018) 143-75.

Lloyd, G. E. R. 'Scholarship, Authority and Argument in Galen's Quod animi mores.' In Le Opere Psicologiche di Galeno: Atti del Terzo Colloquio Galenico Internazionale, Pavia, 10-12 settembre 1986, ed. P. Manuli and M. Vegetti. Naples: Bibliopolis (1988) $11-42$.

Manuli, P. 'La passione nel De placitis Hippocratis et Platonis.' In Le Opere Psicologiche di Galeno: Atti del Terzo Colloquio Galenico Internazionale, Pavia, 10-12 settembre 1986, ed. P. Manuli and M. Vegetti, M. Naples: Bibliopolis (1988) 185-214.

Manuli, P. and Vegetti, M. (eds.) Le Opere Psicologiche di Galeno: Atti del Terzo Colloquio Galenico Internazionale, Pavia, 10-12 settembre 1986. Naples: Bibliopolis (1988).

McDonald, G. C. 'The "locus affectus" in Ancient Medical Theories of Disease.' In Medicine and Space: Body, Surroundings and Borders in Antiquity and the Middle Ages. Visualising the Middle Ages 4, ed. P. A. Baker, H. Nijdam and K. van 't Land. Leiden: Brill (2011) 63-83.

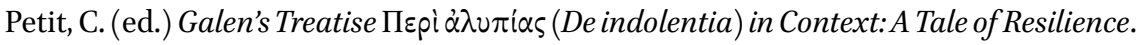
Studies in Ancient Medicine 52. Leiden: Brill (2019).

Petridou, G. and Thumiger, C. (eds.) Homo Patiens: Approaches to the Patient in the Ancient World. Studies in Ancient Medicine 45. Leiden: Brill (2015).

Polito, R. 'Competence Conflicts between Philosophy and Medicine: Caelius Aurelianus and the Stoics on Mental Diseases.' Classical Quarterly, NS 66 (2016) 358-69. 
Singer, P. N. 'Some Hippocratic Mind-Body Problems.' In Tratados Ipocraticos: Estudios acerca de su Contenido, Forma E Influencia: Actas del VII ${ }^{e}$ Colloque International Hippocratique, ed. J. A. López Férez. Madrid: Universidad Nacional de Educación a Distancia (1992) 131-43.

Singer, P. N. (ed.) Galen: Psychological Writings. Avoiding Distress; Character Traits; The Affection and Errors Peculiar to Each Person's Soul; The Capacities of the Soul Depend on the Mixtures of the Body, translated with introductions and notes by V. Nutton, D. Davies and P. N. Singer, with the collaboration of P. Tassinari. Cambridge: Cambridge University Press (2013).

Singer, P. N. 'Galen and the Philosophers: Philosophical Engagement, Shadowy Contemporaries, Aristotelian Transformations.' In Philosophical Themes in Galen. Bulletin of the Institute of Classical Studies Supplement 114, ed. P. Adamson, R. Hansberger and J. Wilberding. London: Institute of Classical Studies (2014) 7-38.

Singer, P. N. 'The Essence of Rage: Galen on Emotional Disturbances and their Physical Correlates.' In Selfhood and the Soul: Essays on Ancient Thought and Literature in Honour of Christopher Gill, ed. R. Seaford, J. Wilkins and M. Wright. Oxford: Oxford University Press (2017) 161-96.

Singer, P. N. 'Galen's Pathological Soul: Diagnosis and Therapy in Ethical and Medical Texts and Contexts.' In Mental Illness in Ancient Medicine: from Celsus to Paul of Aegina. Studies in Ancient Medicine 5o, ed. C. Thumiger and P. N. Singer. Leiden: Brill (2018) 381-420.

Singer, P. N. 'A New Distress: Galen's Ethics in Peri Alupias and Beyond.' In Galen's

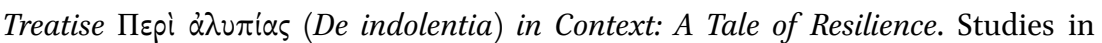
Ancient Medicine 52, ed. C. Petit. Leiden: Brill (2019) 180-98.

Singer, P. N. 'Galen on Pneuma: Between Metaphysical Speculation and Anatomical Theory.' In Pneuma After Aristotle, ed. S. Coughlin, D. Leith and O. Lewis. Berlin: Edition Topoi (forthcoming a).

Singer, P. N. 'What is a Pathos? Where Medicine meets Philosophy.' In Medical Understandings of Emotions, Ancient Emotions 2, ed. G. Kazantzidis and D. Spatharas. Berlin: De Gruyter (forthcoming b).

Singer, P. N., and P. J. van der Eijk. Galen: Works on Human Nature, vol. I: Mixtures (De Temperamentis), Translated with Introduction and Notes. Cambridge: Cambridge University Press (2018).

Thumiger, C. 'The Early Greek Medical Vocabulary of Insanity.' In Mental Disorders in the Classical World. Columbia Studies in the Classical Tradition 38, ed. W. V. Harris. Leiden: Brill (2013).

Thumiger, C. A History of the Mind and Mental Health in Classical Greek Medical Thought. Cambridge: Cambridge University Press (2017).

Thumiger, C., and P. N. Singer (eds.) Mental Illness in Ancient Medicine: from Celsus to Paul of Aegina. Studies in Ancient Medicine 5o. Leiden: Brill (2018). 
Tieleman, T. 'Galen’s Psychology.' In Galien et la philosophie: huit exposés suivis de discussions. Entretiens sur l'antiquité classique 49, ed. J. Barnes, J. Jouanna and V. Barras. Vandoeuvres: Fondation Hardt (2003) 131-69.

Vegetti, M. 'Tradition and Truth: Forms of Philosophical-Scientific Historiography in Galen's De placitis.' In Ancient Histories of Medicine: Essays in Medical Doxography and Historiography in Classical Antiquity, ed. P. J. van der Eijk. Leiden: Brill (1999) 333-57.

Von Staden, H. 'Body, Soul, and Nerves: Epicurus, Herophilus, Erasistratus, the Stoics, and Galen.' In Psyche and Soma: Physicians and Metaphysicians on the Mind-Body Problem from Antiquity to Enlightenment, ed. J. P. Wright and P. Potter. Oxford: Oxford University Press (200o) 79-116.

Von Staden, H. 'The Physiology and Therapy of Anger: Galen on Medicine, the Soul, and Nature.' In Islamic Philosophy, Science, Culture, and Religion: Studies in Honor of Dimitri Gutas, ed. F. Opwis and D. Reisman. Leiden: Brill (2011) 63-87.

Wilkins, J. M. 'Treatment of the Man: Galen's Preventive Medicine in the De sanitate tuenda.' In Homo Patiens: Approaches to the Patient in the Ancient World, Studies in Ancient Medicine 45, ed. G. Petridou and C. Thumiger. Leiden: Brill (2015) 411-31.

Wright, J. P., and P. Potter (eds.) Psyche and Soma: Physicians and Metaphysicians on the Mind - Body Problem from Antiquity to Enlightenment. Oxford: Oxford University Press (2000).

\section{Websites}

https://modernstoicism.com (accessed 7 October 2020)

http://humanities.exeter.ac.uk/history/research/centres/medicalhistory/projects/ healthcareandwellbeing/ (accessed 7 October 2020)

\section{Primary Texts: Editions and Translations Used}

Aretaeus. Ed. C. Hude, CMG II (1923/1958)

Caelius Aurelianus. Acute Diseases and Chronic Diseases. Ed. G. Bendz (with German translation by I. Pape). CML VI 1, 2 vols. (1990/1993). Ed. and trans. I. E. Drabkin, Caelius Aurelianus On Acute Diseases and On Chronic Diseases. Chicago: Chicago University Press (1950).

Celsus. De Medicina. Ed. F. Marx, CML I (1915). Ed. and trans. W. G. Spencer, 3 vols. Loeb Classical Library. Cambridge MA: Harvard University Press (1935/1938).

Galen. Affected Places (= Loc. Aff.). In K. VIII. Books 1 and 2 ed. F. Gärtner, CMG V 6,1,1 (2015).

Galen. Affections and Errors of the Soul (= Aff. Pecc. Dig. 1 and 2). In K. V. Ed. W. de Boer, CMG V 4,1,1 (1937). Trans. in Singer (2013). 
Galen. Avoiding Distress (= Ind.) Ed. V. Boudon-Millot and J.Jouanna, with A. Pietrobelli, Ne pas se chagriner, Paris: Les Belles Lettres (2010). Trans. V. Nutton in Singer (2013). Galen. Causes of Diseases (= Caus. Morb.). In K. VII. Trans. in Johnston (2006). Galen. Causes of Symptoms (= Caus. Symp.). In K. VII. Trans. in Johnston (2006).

Galen. Commentary on Hippocrates' Aphorisms (= Hipp. Aph.). In K. XVIIIA. Book 6 ed. C. Savino, CMG V 12,6 (2020).

Galen. Commentary on Hippocrates' Epidemics VI. In K. XVIIA-B (partial). Ed. including German translation of surviving Arabic portion E. Wenkebach and F. Pfaff, CMG V 10,2,2 (1956).

Galen. Commentary on Hippocrates' Prognostic (= Hipp. Prog.). In K. XVIIIB. Ed. J. Heeg CMG, V 9,2 (1915).

Galen. Commentary on Hippocrates' Nature of the Human Being $(=H N H)$. In K. XV. Ed. J. Mewaldt, CMG V 9,1 (1914).

Galen. Distinctions in Diseases (= Morb. Diff.). In K. VII. Trans. in Johnston (2006).

Galen. Distinctions in Symptoms (= Symp. Diff.). In K. VII. Ed. B. Gundert, CMG V 5,1 (2009). Trans. in Johnston (2006).

Galen. On the Function of the Parts of the Body $(=U P)$. In K. III-IV. Ed. G. Helmreich, Galeni De usu partium, 2 vols., Leipzig: Teubner (1907/19o9). Trans. M. T. May, Galen On the Usefulness of the Parts of the Body, 2 vols. Ithaca: Cornell University Press (1968).

Galen. Matters of Health (= San. Tu.). In K. VI. Ed. K. Koch, CMG V 4,2 (1923). Trans. I. Johnston, Galen: Hygiene, 2 vols. Loeb Classical Library. Cambridge MA: Harvard University Press (2017/2018).

Galen. Mixtures (= Temp.). In K. I. Ed. G. Helmreich, Galeni De temperamentis libri III. Leipzig: Teubner (1904). Trans. in Singer and van der Eijk (2018).

Galen. Prognosis (= Praen.). In K. XIV. Ed. with English translation V. Nutton, CMG V 8,1 (1979).

Galen. Prognosis by the Pulse (= Praes. Puls). In K. IX.

Galen. Sects for Beginners (=SI). In K. I. Ed. G. Helmreich, Claudii Galeni Pergameni Scripta minora, vol. III. Leipzig: Teubner (1893). Trans. in M. Frede and R. Walzer, Galen: Three Treatises on the Nature of Science. Indianapolis: Hackett (1985).

Galen. The Soul's Dependence on the Body $(=Q A M)$. In K. IV. Ed. A. Bazou, $\Gamma \alpha \lambda \eta \nu 0 \hat{0}$ "O $\tau \iota$

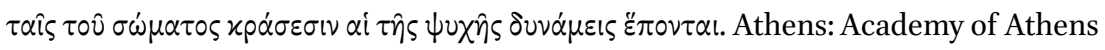
(2011). Trans. in Singer (2013).

Galen. Thrasybulus (= Thras.). In K. V. Ed. G. Helmreich, Claudii Galeni Pergameni Scripta Minora, vol. III. Leipzig: Teubner (1893).

Plutarch. Precepts for Health. Ed. and trans. F. C. Babbitt, Plutarch: Moralia, vol. II. Loeb Classical Library. Cambridge MA: Harvard University Press (1928).

Soranus. Gynaecology. Ed. J. Ilberg, Sorani Gynaeciorum libri IV, CMG IV (1927). 